\title{
ANALISIS HUBUNGAN ANTARA E-SERVICE QUALITY DAN TRUST PADA CUSTOMER SATISFACTION DAN BEHAVIORAL INTENTIONS TELAAH PADA NET GENERATION KONSUMEN LAZADA INDONESIA
}

\begin{abstract}
Kevin Taslim
Universitas Multimedia Nusantara

Internet growing very fast nowadays. One of it's widely known application is online transaction or usually called e-commerce. This research mainly discuss about factors which affect customer behavioral intentions, including word-of-mouth, repurchase intentions and site revisit. Those factors are e-service quality, satisfaction and trust.

The study uses descriptive research design, which use non-probability sampling applying judgemental sampling techniques. The data collected by spreading the questionnaire with total sample of 228 respondents who are Lazada's customer. The hypotheses are tested with structural equation modelling.

The study showed that e-service quality has indirect relationship with behavioral intentions through satisfaction. However, e-service quality is not significantly directly related with behavioral intentions. While trust are strongly related with behavioral intentions.

Keywords: Electronic Commerce, E-Service Quality, Trust, Satisfaction, Online Retailing, Lazada Indonesia

\section{Pendahuluan}

Internet telah digunakan secara luas oleh milyaran pengguna di dunia atau menduduki proporsi $39 \%$ dari penduduk dunia dengan jumlah pengguna internet yang terus bertambah dari waktu ke waktu. Aktivitas yang dapat dilakukan para pengguna internet sangat beragam, mulai dari mengakses informasi terbaru, melakukan social networking, bermain game online, hingga bertransaksi secara online atau dikenal juga sebagai ecommerce.

Penetrasi internet juga terjadi di Indonesia. Survei yang diselenggarakan oleh MarkPlus Insight sejak tahun 2010 menunjukkan bahwa jumlah pengguna internet mengalami peningkatan yang signifikan. Data survei menunjukkan angka pengguna internet di Indonesia mencapai 74,57 juta atau mengalami peningkatan sebesar $22 \%$ dari tahun 2012 ke 2013. Sekitar $42 \%$ dari pengguna Internet tersebut merupakan kategori "Netizen", yaitu mereka yang menghabiskan lebih dari 3 jam sehari untuk online (Marketeers, 2013).
\end{abstract}


Seiring dengan meningkatnya jumlah pengguna internet di Indonesia, market size e-commerce di Indonesia meningkat pesat sejak tahun 2011. Market size $e$ commerce diperkirakan sebesar \$0.9 miliar pada tahun 2011 dan meningkat hingga mencapai \$8 miliar pada tahun 2013 (VelaAsia.com, 2013). Namun, jika dibandingkan dengan total transaksi ritel di Indonesia, jumlah tersebut masih sangat kecil. Total transaksi ritel Indonesia tahun 2013 adalah \$154.9 miliar, sehingga jumlah transaksi e-commerce baru mencapai 5\% dari total transaksi ritel (TradingEconomics.com, 2014).

Lazada, sebuah startup e-commerce asal Malaysia yang bekerja sama dengan Rocket Internet, merupakan pemain besar dalam e-commerce Indonesia. Dengan dukungan dana yang besar sekitar $\$ 100$ juta dari berbagai mitra investor Rocket Internet, Lazada dikatakan sebagai Amazonnya Asia Tenggara (Venture Beat, 2013). Kesuksesan Lazada dalam membangun situs belanja online juga ditunjukkan dengan angka pertumbuhan revenue sebesar 593\% dari tahun 2012 ke 2013 (Kinnevik Q1 2014 Presentation, 2014).

Permasalahan bagi online retailer di Indonesia tidak berakhir pada kecilnya proporsi pengguna internet yang melakukan transaksi e-commerce saja. Survey MarkPlus Insight menunjukkan bahwa hanya $20 \%$ dari responden yang berbelanja di online shop sejenis Lazada, sisanya lebih banyak berbelanja di forum, jejaring sosial dan grup messenger. Hal tersebut juga mengindikasikan bahwa faktor kepercayaan masih menjadi tantangan pada e-commerce Indonesia, karena pelanggan dapat berhubungan langsung dengan penjualnya ketika berbelanja di website yang berbasis sosial.

Sama halnya dengan toko tradisional, sebuah toko online dapat dikatakan hidup apabila banyak yang mengunjungi kembali (site revisit) toko tersebut. Memperoleh pelanggan di internet sangatlah mahal, dan perusahaan sulit mendapatkan profit kecuali jika pelanggan tersebut bertahan dan melakukan banyak repurchase (Reichheld \& Schefter, 2000). Maka, repurchase intention pelanggan penting bagi sebuah bisnis. Word-of-mouth (WOM) tidak kalah penting dengan faktor lainnya, karena WOM merupakan salah satu alat promosi yang efektif. Reichheld \& Schefter (2000) menyebutkan bahwa perusahaan Vanguard menghabiskan hanya $10 \%$ dari biaya iklan yang dikeluarkan oleh kompetitornya, dan bahkan mendapatkan pelanggan baru lebih cepat dibandingkan kebanyakan kompetitornya karena rekomendasi melalui WOM. Site revisit, repurchase intention dan word-of-mouth merupakan bagian behavioral intentions, yakni faktor yang penting bagi kesuksesan sebuah perusahaan online (Gounaris, Dimitriadis, \& Stathakopoulos, 2010). Kotler \& Keller (2012) menyebutkan bahwa praktek wordof-mouth seperti ulasan dan rekomendasi dari pelanggan, merupakan salah satu faktor yang berperan penting pada kesukesan online retailer seperti Amazon dan Shop.com.

Kassim \& Abdullah (2010), memperoleh kesimpulan bahwa customer satisfaction dan trust memiliki efek yang signifikan pada kesetiaan melalui WOM yang merupakan antecedent dari repeat visits \& repurchase intentions.

Hal yang tidak kalah penting adalah para pelanggan yang tergolong dalam $\mathrm{Net}$ Generation atau Generasi Y yang lahir antara tahun 1977 hingga 1997. Profil pengguna internet pada tahun 2012 menunjukkan bahwa pengguna internet di Indonesia didominasi oleh pengguna berusia muda antara 12-34 tahun dengan proporsi sebesar $58.4 \%$ dari total pengguna internet. Hal ini berarti, pelanggan dari perusahaan-perusahaan online sebagian besar akan berasal dari Net Generation, sehingga mereka memiliki pengaruh besar bagi perusahaan online. 
Berdasarkan respon kualitatif dari 228 responden Lazada.co.id, ternyata masih banyak yang mengeluhkan mengenai halhal yang berkaitan erat dengan e-service quality. Penelitian kualitatif ini dilakukan dengan meminta responden untuk menuliskan komentar dan saran mereka tentang Lazada.co.id. Ternyata, cukup banyak yang menuliskan tentang masalah pengiriman di Lazada.co.id, mulai dari pengiriman terlambat lebih dari seminggu hingga keadaan packing yang rusak ketika sampai di tangan pelanggan. Hal ini berhubungan erat dengan variabel fulfillment yang merupakan salah satu dari dimensi e-service quality.

Selain itu juga banyak yang mengeluhkan tentang sulitnya Lazada.co.id untuk diakses saat flash sale. Hal ini berhubungan erat dengan variabel system realibility sebagai dimensi dari $e$ service quality. Sejumlah pelanggan mengeluhkan tentang tampilan Lazada.co.id yang terlalu ramai dan menyebabkan loading-nya menjadi berat. Selain itu juga ditemukannya bugs dan error terutama pada sistem search filter. Hal ini sangat berhubungan dengan variabel efficiency dan aesthetics yang merupakan dimensi dari e-service quality. Maka, dapat dilihat adanya indikasiindikasi mengenai masalah e-service quality di Lazada.co.id.

Berdasarkan uraian tersebut maka peneliti menetapkan masalah penelitian sebagai berikut :

1. Apakah e-service quality
berpengaruh positif terhadap
satisfaction?

2. Apakah e-service quality berpengaruh positif terhadap behavioral intentions?

3. Apakah satisfaction berpengaruh positif terhadap behavioral intentions?

4. Apakah trust berpengaruh positif terhadap behavioral intentions?

\section{Tinjauan Literatur dan Hipotesis}

Retailer harus membangun hubungan yang dapat dipercaya untuk meningkatkan penjualan di internet dan menciptakan kesetiaan pelanggan. Tidak adanya kehadiran dan interaksi antara produk, pembeli dan penjual secara fisik, hubungan yang sulit diamati, dan cyberlaws yang tidak jelas, menjadikan online retailing sebagai hal yang unik dimana trust menjadi faktor yang sangat penting (Mukherjee \& Nath, 2007).

Pentingnya quality pada service maupun produk telah dijelaskan oleh berbagai literatur. Salah satunya menyatakan bahwa kualitas produk dan pelayanan saling berhubungan dengan kepuasan pelanggan dan profitabilitas perusahaan. Semakin tinggi kualitas, pelanggan semakin puas, sehingga perusahaan dapat memberikan harga yang lebih tinggi (Kotler \& Keller, 2012).

Pemasaran banyak berbicara mengenai pelanggan, salah satu hal yang sering menjadi perhatian adalah mengenai kepuasan pelanggan. Tsiros, Mittal \& Ross (2004) dalam Kotler \& Keller (2012) menyatakan bahwa kepuasan adalah perasaan senang atau kecewa yang dirasakan ketika membandingkan performa produk yang dirasakan dengan ekspektasi. Penelitian Keaveney \& Parthasarathy (2001) menyatakan bahwa pada masa post-purchase, aktivitas pemasaran perlu didesain untuk meningkatkan customer satisfaction, involvement, dan service usage untuk mencegah pelanggan melakukan switching.

Sedangkan Gounaris, Dimitriadis, \& Stathakopoulos (2010) menyebutkan bahwa para manajer perlu membuat strategi yang customer-oriented pada tahap postpurchase, yaitu strategi yang didesain untuk meningkatkan customer satisfaction. Riset menunjukkan bahwa pelanggan 
online yang puas akan berbelanja lebih banyak, menghabiskan lebih banyak uangnya, dan lebih sering melakukan pembelian. Konsumen yang puas mempunyai perilaku yang berbeda dengan yang tidak puas, dimana perilaku konsumen yang puas memiliki efek positif pada berbagai aspek penting yang berhubungan dengan operating profit (Boston Consulting Group, 2001).

Pada penelitian ini, definisi dari behavioral intentions adalah probabilitas subjektif seseorang untuk melakukan perilaku tertentu. Definisi tersebut merujuk pada teori Fishbein \& Ajzen (1975). Penilitian ini mengukur behavioral intentions dengan tiga dimensi, yaitu repurchase intentions, site revisit dan word-of-mouth merujuk pada penelitian Gounaris, Dimitriadis, \& Stathakopoulos (2010).

Repurchase intention diartikan sebagai kesediaan pelanggan untuk membeli lebih banyak melalui Internet (Gounaris, Dimitriadis, \& Stathakopoulos, 2010). Sedangkan menurut Hellier, Geursen, Carr, \& Rickard (2003) repurchase intentions adalah Keputusan seseorang untuk membeli kembali di perusahaan yang sama dengan mempertimbangkan situasi saat ini dan keadaan yang mungkin terjadi.

Dengan memberikan informasi terpercaya mengenai kualitas produknya, maka customer trust akan meningkat dan besarnya kepercayaan pelanggan akan meningkatkan kesetiaan terhadap website, sedangkan salah satu indikator dari kesetiaan adalah customer intention to purchase (Brilliant \& Achyar, 2013). Penelitian lain menemukan bahwa trust mempunyai dampak yang signifikan terhadap loyalitas melalui word-of-mouth (Kassim \& Abdullah, 2010). Reichheld \& Schefter (2000) menyebutkan bahwa untuk mendapatkan kesetiaan dari pelanggan, yang terlebih dahulu harus didapatkan adalah trust dari mereka. Hal tersebut didukung oleh penelitian yang membahas mengenai e-servicescape, yang salah satu temuannya menjelaskan bahwa loyalty intentions pelanggan online berhubungan erat dengan tingkat kepercayaan mereka terhadap website (Harris \& Goode, 2010). Hubungan variabel trust terhadap behavioral intention didukung oleh penelitian lainnya yang menemukan hubungan positif antara trust dengan behavioral intention (Cyr, 2008; Afsar, Nasiri, \& Zadeh, 2013). Baik trust \& commitment memiliki pengaruh yang signifikan pada customer behavioral intentions. Jika tingkat trust \& commitment tinggi, maka positive word-ofmouth akan lebih mungkin terjadi, karena pelanggan akan memberikan rekomendasi positif pada orang lain ketika ia mempercayai sebuah online retailer. Selain itu, pelanggan yang telah memiliki trust pada suatu website, akan selalu mempertimbangkan untuk melakukan pembelian dengannya. Dalam hal ini, trust mempunyai pengaruh yang besar pada customer purchase intentions. (Mukherjee \& Nath, 2007).

Service quality dapat meningkatkan favorable behavioral intentions dan menurunkan unfavorable behavioral intentions (Zeithaml, Berry, \& Parasuraman, 1996). Penelitian lebih lanjut oleh Zeithaml, Parasuraman, \& Malhotra (2002) memberikan kesimpulan bahwa eservice quality mempengaruhi satisfaction, intent to purchase, dan purchase. Lebih lanjut dijelaskan bahwa didapatkan cukup data untuk menyatakan bahwa e-service quality merupakan key driver dari repeat purchase dari website. Pada umumnya, negative WOM disebabkan oleh ketidakpuasan yang dirasakan pelanggan karena e-service quality yang rendah (Gounaris, Dimitriadis, \& Stathakopoulos, 2010). Sedangkan penelitian mengenai ES-QUAL menemukan bahwa keempat dimensinya yakni, efficiency, fulfillment, system availability serta privacy mempunyai pengaruh kuat pada persepsi pelanggan terhadap overall quality perception, perceived value dan loyalty 
intentions, di mana loyaty intentions pada penelitian ini mencakup positive word-ofmouth dan repurchase intention (Parasuraman, Zeithaml, \& Malhotra, 2005). Temuan ini didukung oleh penelitian Lee \& Lin (2005) yang menemukan hubungan positif antara overall service quality, customer satisfaction dan purchase intentions dalam sebuah online store.

Keempat key drivers dari e-service quality, yaitu information, user friendliness, adaptation dan aesthetics pada penelitian Gounaris, Dimitriadis, \& Stathakopoulos (2010), mempunyai dampak yang signifikan pada satisfaction. Temuan tersebut didukung oleh penelitian lain yang menyebutkan bahwa e-service quality mempengaruhi satisfaction, intent to purchase, dan purchase (Zeithaml, Parasuraman, \& Malhotra, 2002). Studi lainnya oleh Yang \& Fang (2004) yang membahas online service quality, menemukan bahwa dimensi service quality mengarah kepada customer satisfaction (Yang \& Fang, 2004). Penelitian serupa dilakukan oleh Kassim \& Abdullah (2010) menemukan bahwa Perceived service quality mempunyai pengaruh pada customer satisfaction. Temuan lainnya yang menunjukkan bahwa dimensi dari $e$ service quality yaitu website design, realibility, responsiveness dan trust mempengaruhi overall service quality serta customer satisfaction (Lee \& Lin, 2005).

Baik customer satisfaction dan trust mempunyai dampak yang signifikan terhadap loyalitas melalui word-of-mouth (Kassim \& Abdullah, 2010). Pelanggan yang satisfied enggan untuk berpindah pada retailer alternatif hanya untuk benefit jangka pendek (Mukherjee \& Nath, 2007). Penelitian oleh Gounaris, Dimitriadis, \& Stathakopoulos (2010) menunjukkan bahwa tingginya quality dan satisfaction mendorong site revisit serta word-of- mouth. Hubungan mengenai satisfaction juga ditunjukkan oleh penelitian (Lee \& Lin, 2005) yang menyatakan bahwa customer satisfaction berpengaruh secara signifikan pada customer purchase intentions. Penelitian lain menemukan hubungan positif antara satisfaction dengan perceived intention to visit dan purchase (Cyr, 2008).

Penelitian tentang e-service quality yang dilakukan oleh Gounaris, Dimitriadis, \& Stathakopoulos (2010) digunakan sebagai jurnal utama dalam penelitian ini. Temuan inti dari penelitian Gounaris, Dimitriadis, \& Stathakopoulos (2010) menunjukkan hubungan antara e-service quality dengan behavioral intentions secara langsung maupun tidak langsung melalui satisfaction. Sedangkan modifikasi dilakukan terhadap model penelitian dengan menambahkan variabel trust berdasarkan penelitian Mukherjee \& Nath (2007).

Terdapat beberapa penelitian dan jurnal pendukung yang berkaitan dengan service quality, customer satisfaction, trust dan behavioral Intentions.

\section{III.Metode Penelitian}

Dalam penelitian ini digunakan Deskriptive Research Design, yaitu dengan metode survey. Dilaksanakan dengan menyebarkan kuesioner kepada responden, dimana responden menjawab pertanyaan dengan memberikan nilai antara 1 sampai 5 skala likert.

Element dari penelitian ini adalah pelanggan Lazada Indonesia yang merupakan Net Generation (berumur 1735 tahun), yang berbelanja melalui website Lazada.co.id dalam kurun waktu 3 bulan terakhir dan pernah berbelanja online di tempat lain. Sampling unit-nya adalah seluruh pelanggan Lazada.co.id yang berumur 17-35 tahun. Pelanggan yang berbelanja pada kurun waktu 3 bulan 
diperkirakan masih dapat mengingat pengalaman berbelanja di Lazada dengan baik, dan diasumsikan belum ada perubahan yang besar pada Lazada dalam waktu 3 bulan. Maka, kriteria 3 bulan dianggap paling tepat dan memudahkan peneliti untuk mencari responden.

Extent atau batas geografis dari penelitian ini adalah negara Indonesia. Pembatasan extent untuk negara Indonesia saja dimaksudkan untuk mengambil scope yang tidak terlalu luas, sehingga hasil penelitian ini dapat disimpulkan secara optimal dan lebih akurat. Selain itu, objek dari penelitian ini adalah Lazada.co.id, yang merupakan cabang dari online store Lazada yang beroperasi khusus untuk wilayah Indonesia saja. Pada penelitian ini, terdapat total 43 pertanyaan pada kuesioner, sehingga jumlah variabel teramati dalam penelitian ini adalah 43 indikator.

Analisa hasil penelitian menggunakan metode SEM (Structural Equation Modeling) karena model penelitian ini memiliki lebih dari 1 variabel endogen. Software yang digunakan adalah AMOS (Analysis Of Moment Structure) versi 22 untuk melakukan uji validitas, realibilitas, hingga uji hipotesis penelitian.

Terdapat enam tahap dalam penelitian ini. Tahap pertama adalah mendefinisikan masing-masing construct dan indikatorindikator untuk mengukurnya. Kemudian tahap selanjutnya adalah membuat diagram measurement model atau model pengukuran. Tahap selanjutnya adalah menentukan kecukupan dari sample size dan memilih metode estimasi dan pendekatan untuk menangani missing data. Selanjutya adalah mengukur validitas atau kecocokan model pengukuran. Jika model pengukuran dapat dikatakan valid, maka dapat dilanjutkan ke tahap 5 dan 6 . Tahap kelima adalah mengubah model pengukuran menjadi model struktural. Kemudian tahap terakhir adalah menilai validitas atau kecocokan model struktural. Jika model struktural memiliki tingkat kecocokan yang baik, maka selanjutnya dapat diambil kesimpulan penelitian.

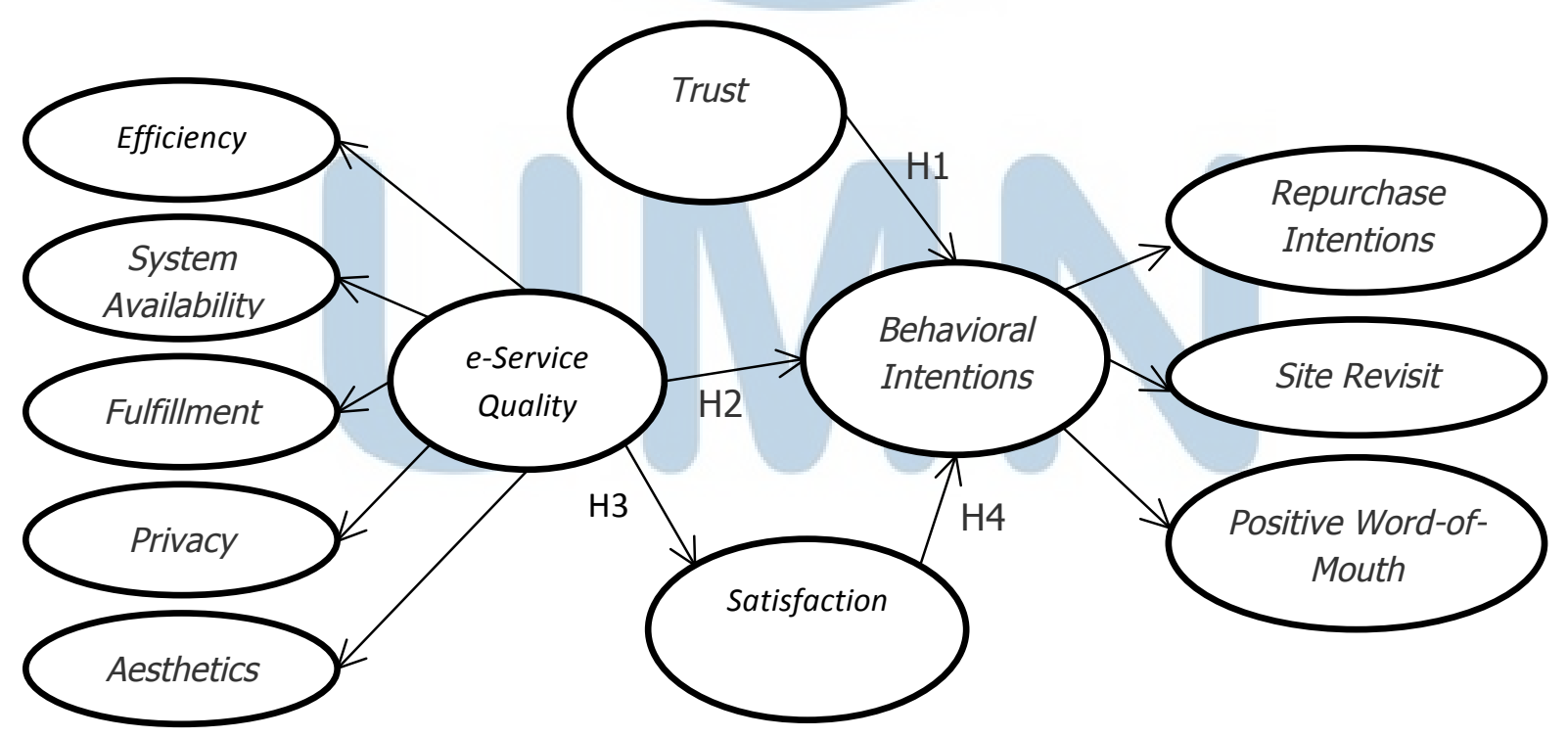

Gambar 2.1 Model Penelitian

Sumber : Gounaris, Dimitriadis, \& Stathakopoulos (2010); Parasuraman, Zeithaml, \& Malhotra (2005); Mukherjee \& Nath (2007) 


\section{IV.Hasil dan Pembahasan}

Terdapat 228 responden dalam penelitian ini. Mayoritas responden menghabiskan waktu kurang 30 menit ketika mengakses Lazada.co.id. Namun, hanya sedikit dari mereka yang biasa menghabiskan waktu dibawah 5 menit ketka mengakses
Lazada.co.id, yaitu sekitar 3\% dari total responden atau sejumlah 8 orang. Sebanyak $34 \%$ dari total responden menghabiskan waktu antara 5-15 menit ketika mengakses Lazada.co.id, $43 \%$ atau sebanyak 103 orang menghabiskan waktu antara 15-30 menit, dan sisanya menghabiskan lebih dari 30 menit.

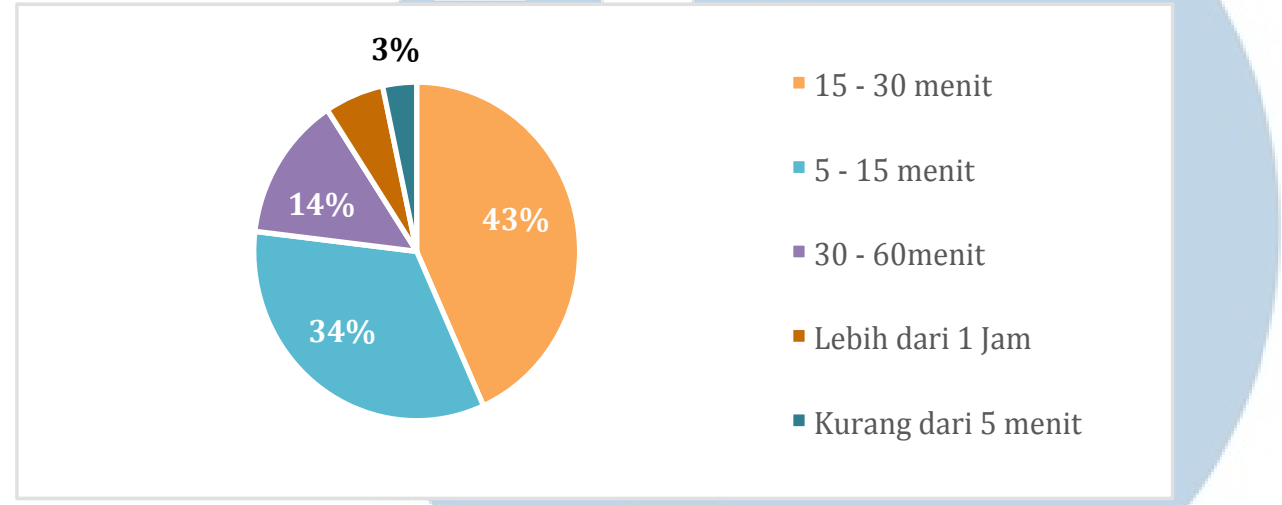

Grafik 4.1 Rata-Rata Waktu yang Dihabiskan untuk Mengakses Lazada.co.id Sumber : Pengolahan Data Primer, 2014

Sebanyak $52 \%$ dari responden menghabiskan antara Rp 100.000 - Rp 499.000 dalam sekali berbelanja di Lazada.co.id, diikuti dengan responden yang menghabiskan antara Rp 1.000.000 Rp 4.999.000 dalam satu kali berbelanja sebanyak $33 \%$ atau 79 orang. Diprediksikan bahwa pembelanja di rentang harga $\mathrm{Rp} \quad 1.000 .000 \quad-\mathrm{Rp}$
4.999.0000 adalah mereka yang membeli produk Gadget, komputer, maupun laptop. Kemudian, sisanya menghabiskan antara Rp 500.000 - Rp 999.000 dan hanya 2\% dari responden yang menghabiskan kurang dari Rp 100.000 ketika berbelanja di Lazada.co.id. Hal ini dapat dilihat pada grafik 4.2. 

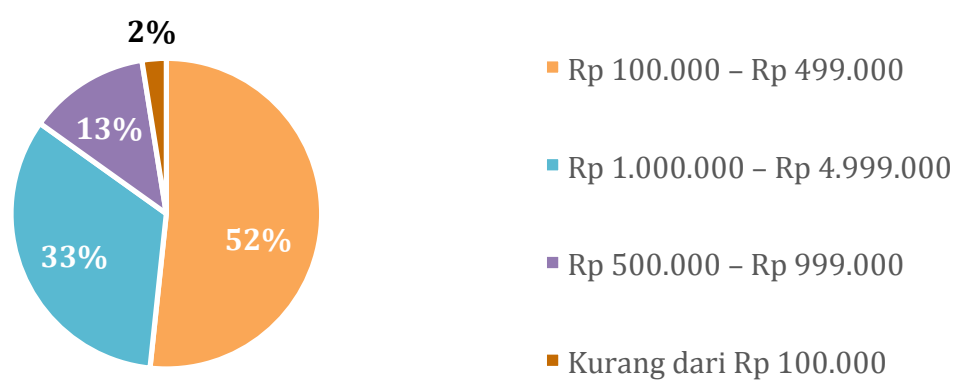

Grafik 4.2 Rata-Rata Pengeluaran dalam Sekali Berbelanja di Lazada.co.id Sumber : Pengolahan Data Primer, 2014

Hasil penelitian juga menunjukan bahwa gadget adalah produk yang paling banyak dibeli di Lazada.co.id, yaitu sebanyak $72.27 \%$ dari responden membeli produk gadget pada transaksi terakhirnya di Lazada, kemudian disusul oleh produk fashion dan aksesoris sebanyak $19.75 \%$, produk audio sebanyak $16.39 \%$ dan sisanya produk peralatan rumah tangga, kesehatan kecantikan, otomotif dan hobi kemudian snack impor. Hal ini terlihat pada Grafik 4.3.

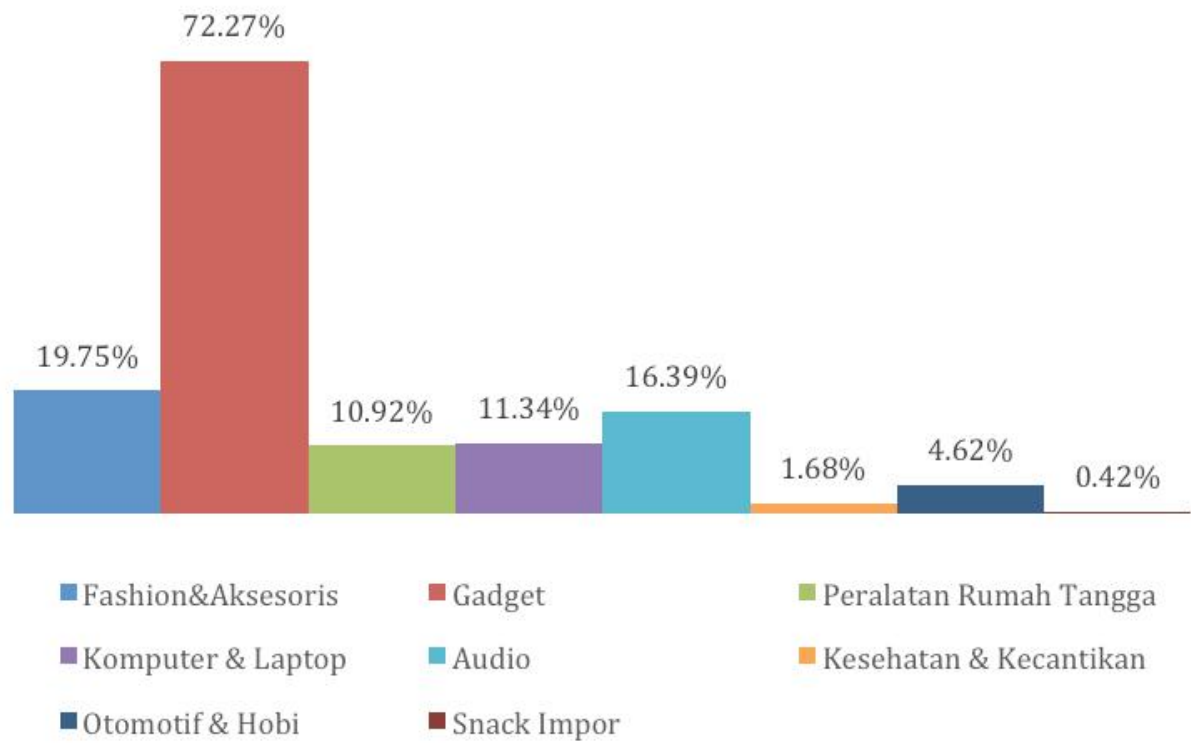

Grafik 4.3 Produk yang Terakhir Kali Dibeli oleh Konsumen Sumber : Pengolahan Data Primer, 2014

Informasi yang ditunjukkan oleh Grafik 4.4 ternyata sejalan dengan hasil survey Netizen Indonesia 2013 bahwa konsumen lebih menyukai metode pembayaran transfer bank (57\%) dan diikuti oleh metode COD (31\%). Pembayaran menggunakan kartu kredit sangatlah kecil peminatnya, yaitu hanya sekitar $7 \%$ atau sebanyak 16 responden memilih metode pembayaran tersebut. Responden juga ternyata belum terbiasa menggunakan alternatif pembayaran modern seperti BCA KlikPay, ditunjukkan oleh angka yang cukup kecil, yaitu hanya sekitar 5\% dari total responden. 


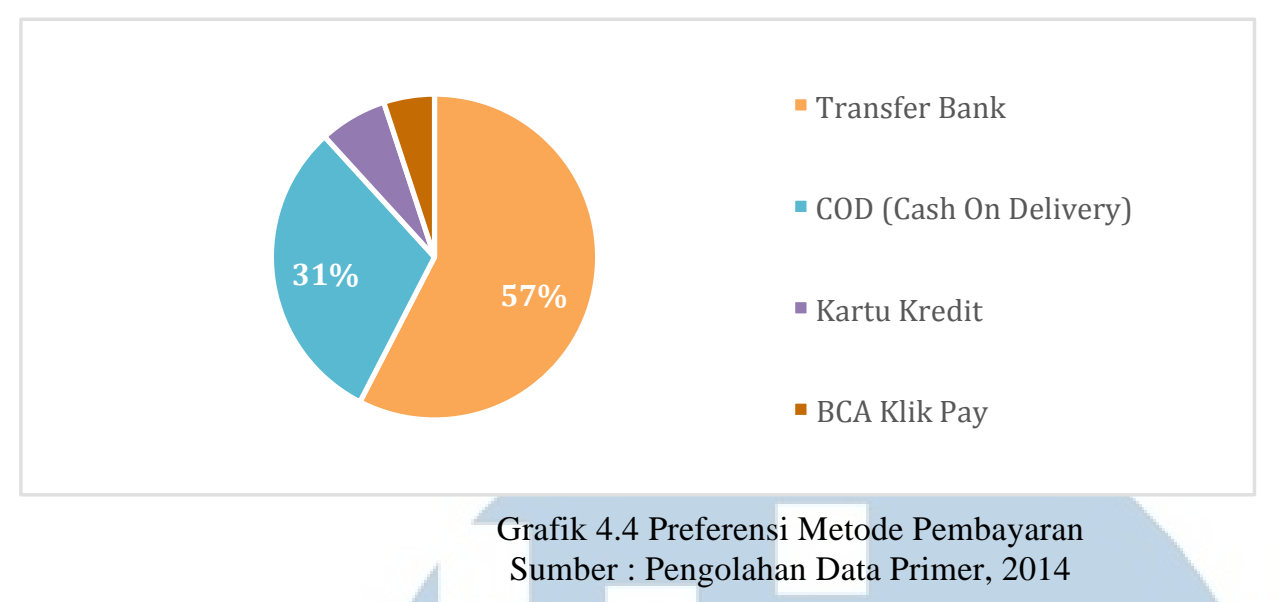

Uji structural model dilakukan dengan mengukur goodness of fit model. Goodness of Fit dilihat berdasarkan kecocokan absolute measurement model, kecocokan incremental measurement model dan kecocokan parsimoniuos measurement model. Pengolahan data untuk mendapatkan hasil estimasi, dilakukan dengan menggunakan aplikasi Amos versi 22. Hasil keseluruhan uji model disajikan dalam tabel berikut ini :

Tabel 4.1 Tabel Kecocokan Absolute Measurement Model

\begin{tabular}{|c|c|c|c|}
\hline Ukuran GOF & $\begin{array}{l}\text { Target Tingkat } \\
\text { Kecocokan } \\
\text { Ukuran Kecoc }\end{array}$ & $\begin{array}{l}\text { Hasil Estimasi } \\
\text { an Absolut }\end{array}$ & $\begin{array}{l}\text { Tingkat } \\
\text { Kecocokan }\end{array}$ \\
\hline $\begin{array}{l}\text { Chi-Square } \\
\mathrm{P} \geq 0,05\end{array}$ & $\begin{array}{c}\text { Nilai yang kecil } \\
P \geq 0,05 \\
\text { GFI } \geq 0,90\end{array}$ & $\begin{array}{c}1594.825 \\
0.000\end{array}$ & Poor Fit \\
\hline (GFI) & $\begin{array}{c}0,80 \leq \mathrm{GFI}<0,90 \\
\mathrm{GFI}<0,80\end{array}$ & 0.758 & Poor Fit \\
\hline (RMSEA) & $\begin{array}{c}\text { RMSEA } \leq 0,08 \\
0,08 \leq \text { RMSEA }<0,10 \\
\text { RMSEA } \geq 0,10 \\
\text { Nilai yang kecil dan } \\
\text { dekat dengan nilai } \\
\text { ECVI saturated }\end{array}$ & $\begin{array}{c}0.069 \\
\text { DM : } 7.854 \\
\text { SM : } 7.586 \\
\text { IM : } 33.466\end{array}$ & Good Fit \\
\hline
\end{tabular}

Tabel 4.2 Tabel Kecocokan Incremental Measurement Model

\begin{tabular}{|c|c|c|c|}
\hline Ukuran GOF & $\begin{array}{l}\text { Target Tingkat } \\
\text { Kecocokan } \\
\text { Ukuran Keco }\end{array}$ & $\begin{array}{l}\text { Hasil Estimasi } \\
\text { In Incremental }\end{array}$ & $\begin{array}{c}\text { Tingkat } \\
\text { Kecocokan }\end{array}$ \\
\hline TLI & $\begin{array}{c}\text { TLI } \geq 0,90 \\
0,80 \leq \mathrm{TLI}<0,90 \\
\text { TLI }<0,80\end{array}$ & 0.868 & Marginal Fit \\
\hline NFI & $\begin{array}{c}\mathrm{NFI} \geq 0,90 \\
0,80 \leq \mathrm{NFI}<0,90\end{array}$ & 0.788 & Poor Fit \\
\hline
\end{tabular}




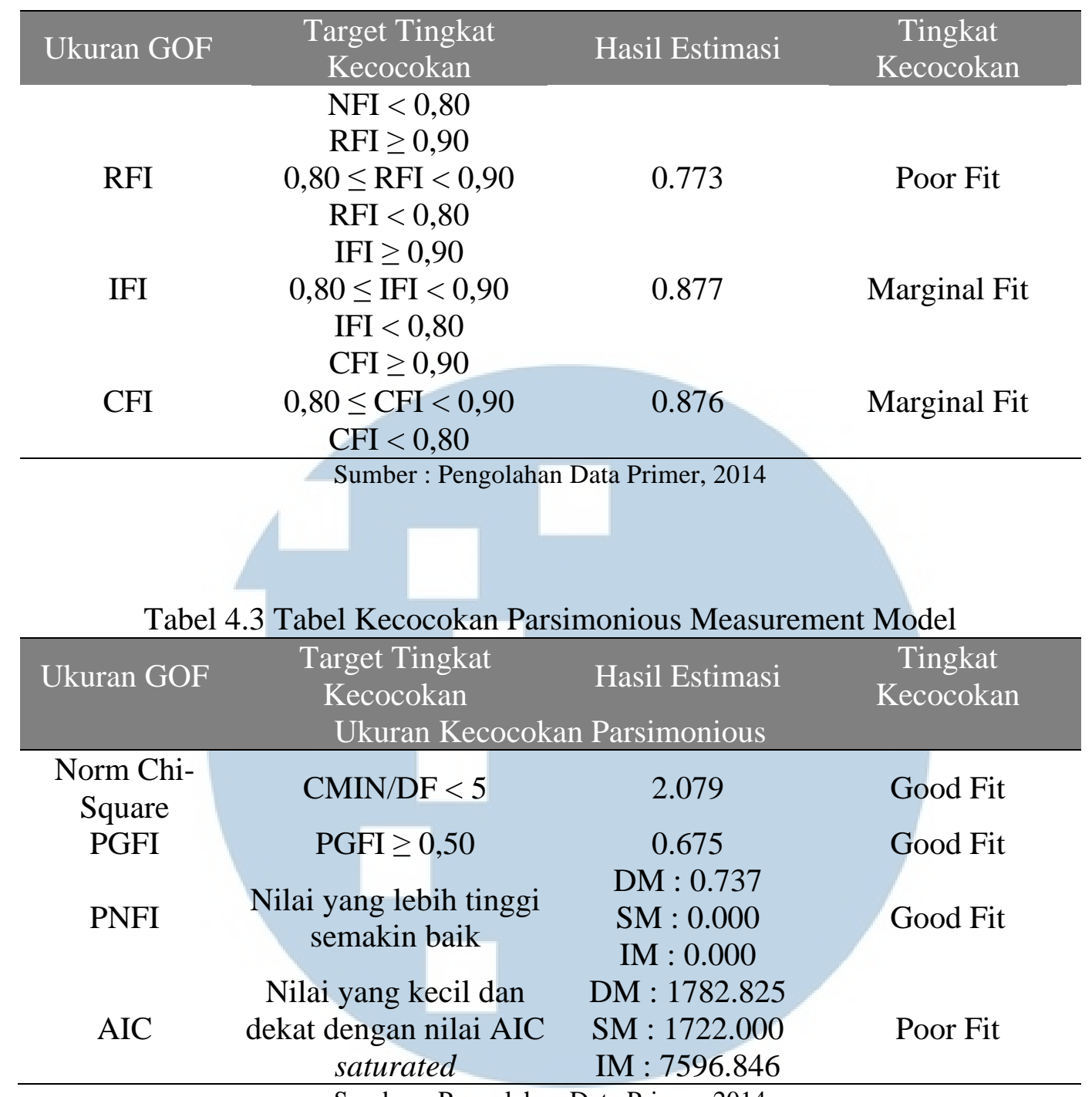

Pada tabel 4.1 menunjukkan pengukuran Chi-Square, GFI, dan ECVI memiliki tingkat kecocokan poor fit dan RMSEA memiliki tingkat kecocokan good fit. Tabel 4.2 menunjukkan bahwa TLI, IFI, CFI memiliki tingkat kecocokan yang cukup baik yaitu tergolong marginal fit dan hanya RFI dan NFI yang memiliki tingkat kecocokan poor fit. Tabel 4.3 menunjukkan Norm Chi-Square, PGFI, PNFI memiliki tingkat kecocokan good fit, dan AIC memiliki tingkat kecocokan poor fit. Dengan banyaknya tingkat kecocokan marginal fit dan good fit dibandingkan dengan poor fit, dan RMSEA, CFI serta Norm-Chi Square tidak bernilai poor fit, maka dapat disimpulkan bahwa model memiliki goodness of fit yang cukup baik dengan mempertimbangkan nilai RMSEA, CFI dan Norm Chi-Square yang memadai serta jumlah poor fit yang lebih sedikit dibanding marginal fit dan good fit. Maka, dengan hasil uji kecocokan yang baik dapat dilanjutkan pengolahan datanya untuk mendapatkan kesimpulan penelitian. Pada gambar 4.1 ditampilkan path diagram hasil estimasi model berdasarkan output AMOS 22. 


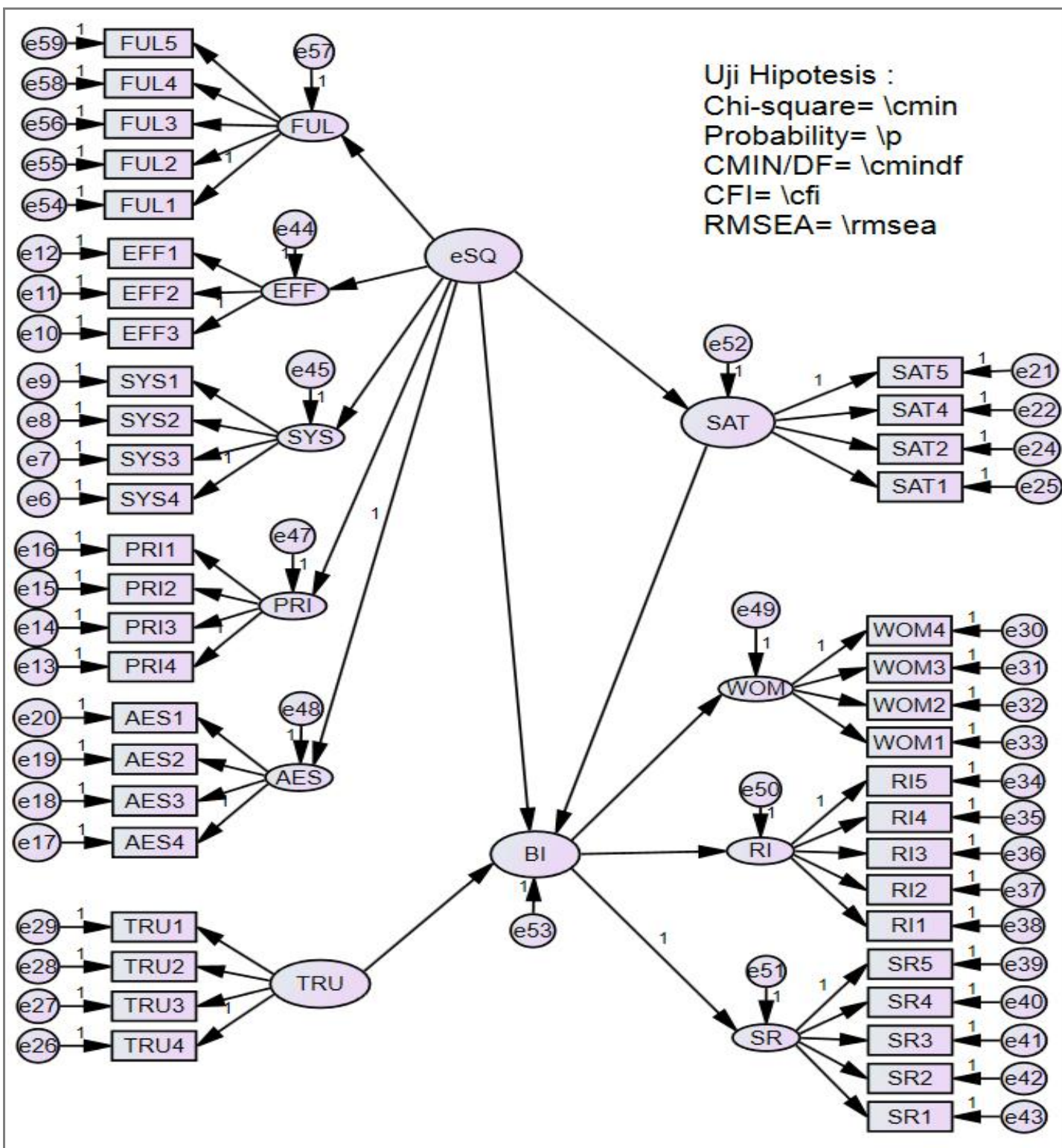

Gambar 4.1 Path Diagram

Sumber : Pengolahan Data Primer, 2014

Tabel 4.4 Hasil Uji Hipotesis

Hipotesis

Pernyataan
Std. Coef

\section{$\mathrm{P}$ Value}

$<0.05$

Trust mempunyai pengaruh

H1: TRU -> BI positif terhadap Behavioral Intentions

e-Service quality memiliki

H2: eSQ -> BI pengaruh positif secara langsung terhadap behavioral intentions

H3: eSQ -> SAT $\begin{aligned} & \text { e-Service quality memiliki } \\ & \text { pengaruh positif terhadap }\end{aligned}$

$\begin{array}{lll}+0.175 & 0.001 & \text { Data } \\ \text { mendukung } \\ \text { Hipotesis 1 } \\ & & \text { Data tidak }\end{array}$

$-0.840$

0.388

mendukung

Hipotesis 2

\begin{tabular}{lll}
+1.194 & 0.0000 & $\begin{array}{l}\text { Data } \\
\text { mendukung }\end{array}$ \\
\hline
\end{tabular} 


\begin{tabular}{clccl}
\hline Hipotesis & \multicolumn{1}{c}{ Pernyataan } & Std. Coef $\begin{array}{c}\text { P Value } \\
<0.05\end{array}$ & Kesimpulan \\
\hline H4: SAT -> BI & $\begin{array}{l}\text { satisfaction } \\
\text { satisfaction memiliki } \\
\text { pengaruh positif terhadap } \\
\text { Behavioral Intentions }\end{array}$ & +1.690 & 0.031 & $\begin{array}{l}\text { Hipotesis 3 } \\
\text { Data } \\
\text { mendukung } \\
\text { Hipotesis 4 }\end{array}$ \\
\hline
\end{tabular}

Sumber : Pengolahan data primer, 2014

Tabel 4.4 di atas menunjukkan bahwa $\mathrm{H} 1$ mempunyai standard coefficients yang bernilai positif, menandakan bahwa hasil uji hipotesis yang sedang diuji menunjukkan arah hubungan positif, sesuai dengan pernyataan hipotesis yang telah dibuat. Nilai $P$ Value adalah 0.001 atau bernilai lebih kecil dari 0.05 , maka dapat disimpulkan bahwa data mendukung Hipotesis 1.

H2 mempunyai standard coefficients yang bernilai negatif, menandakan bahwa hasil uji hipotesis yang sedang diuji menunjukkan arah hubungan negatif, tidak sesuai dengan pernyataan hipotesis yang telah dibuat. Nilai $P$ Value adalah 0.388 atau bernilai lebih besar dari 0.05 , maka dapat disimpulkan bahwa data tidak mendukung Hipotesis 2.

H3 mempunyai standard coefficients yang bernilai positif, menandakan bahwa hasil uji hipotesis yang sedang diuji menunjukkan arah hubungan positif, sesuai dengan pernyataan hipotesis yang telah dibuat. Nilai $P$ Value adalah 0.0000 atau bernilai lebih kecil dari 0.05 , maka dapat disimpulkan bahwa data mendukung Hipotesis 3.

H4 mempunyai standard coefficients yang bernilai positif, menandakan bahwa hasil uji hipotesis yang sedang diuji menunjukkan arah hubungan positif, sesuai dengan pernyataan hipotesis yang telah dibuat. Nilai $P$ Value adalah 0.031 atau bernilai lebih kecil dari 0.05 , maka dapat disimpulkan bahwa data mendukung Hipotesis 4.

Uji hipotesis penelitian ini menunjukkan bahwa trust memiliki hubungan positif terhadap behavioral intentions. Standard coefficients yang bernilai 0.175 menunjukkan adanya korelasi yang kuat antara trust dengan behavioral intentions. Hal ini menunjukkan bahwa tingginya tingkat kepercayaan pelanggan terhadap Lazada.co.id, sangat mempengaruhi kecenderungan pelanggan untuk melakukan repurchase, menyebarkan positive word-of-mouth dan mengunjungi kembali website-nya.

Hasil penelitian ini sesuai dengan temuan Mukherjee \& Nath (2007) yang menyatakan bahwa trust memiliki pengaruh yang signifikan pada customer behavioral intentions. Pelanggan akan memberikan rekomendasi positif pada orang lain ketka ia mempercayai sebuah online retailer dan pelanggan yang telah memiliki trust pada suatu website, akan selalu mempertimbangkan untuk melakukan pembelian dengannya. Maka, dapat ditarik kesimpulan bahwa semakin kuat trust pelanggan Lazada.co.id maka behavioral intentions juga semakin kuat.

Pelanggan Lazada.co.id menginginkan toko online yang dapat dipercaya untuk bertransaksi. Artinya, toko online tersebut cukup profesional untuk menjaga keamanan informasi pribadi mereka, informasi pembayaran mereka, dan memberikan rasa aman bagi mereka dengan memberikan pelayanan sesuai yang dijanjikan. Rasa percaya yang dirasakan oleh pelanggan akan mendorong mereka untuk mengatakan hal positif tentang Lazada.co.id, berbelanja kembali dan mengunjungi kembali Lazada.co.id. Uji hipotesis penelitian ini menunjukkan bahwa e-service quality tidak memiliki hubungan dengan behavioral intentions. Nilai $p$-value sebesar 0.388 menunjukkan bahwa tidak ada pengaruh yang cukup 
signifikan dari e-service quality ke behavioral intentions secara langsung.

Hal ini tidak sesuai dengan temuan Gounaris, Dimitriadis, \& Stathakopoulos (2010) yang menyatakan bahwa e-service quality memiliki hubungan dengan behavioral intentions secara langsung. Meskipun tidak memiliki hubungan secara langsung, e-service quality mempunyai hubungan secara tidak langsung dengan behavioral intentions melalui satisfaction. Artinya, pelanggan yang menilai baik $e$ service quality Lazada.co.id akan terlebih dahulu merasa puas, yang kemudian rasa puas tersebut akan meningkatkan kecenderungan pelanggan untuk menyebarkan hal positif tentang Lazada.co.id, melakukan repurchase dan site revisit.

Hal ini sangat masuk akal, karena tentunya hanya mereka yang sudah merasa puas dan percaya dengan Lazada.co.id yang akan lebih cenderung untuk melakukan repurchase dan berani memberikan rekomendasi positif tentang Lazada.co.id. Memberikan kualitas navigasi website yang baik, menyediakan website yang menarik, memiliki sistem yang handal, akan menjadi sia-sia jika pada akhirnya tidak mampu membuat pelanggan puas dan percaya. Hal lain yang mungkin terkait adalah karena hampir 50\% dari responden mempunyai rata-rata pengeluaran lebih dari Rp 500.000 dalam sekali berbelanja di Lazada.co.id dan sekitar $72 \%$ dari responden membeli kategori produk gadget pada pembelian terakhirnya. Karena transaksi-transaksi tersebut bernominal cukup besar, maka tentunya diperlukan lebih dari sekedar e-service quality yang dimensinya didominasi oleh variabel-variabel yang terkait dengan kualitas website. Trust dan satisfaction akan menjadi driver yang lebih penting untuk behavioral intentions pada kondisi transaksi bernominal besar.
Uji hipotesis penelitian ini menunjukkan bahwa e-service quality memiliki hubungan positif terhadap satisfaction. Standard coefficients yang bernilai 1.194 menunjukkan adanya korelasi antara $e$ service quality dengan satisfaction, namun bukan merupakan korelasi yang kuat. Hal ini menunjukkan bahwa tingginya $e$ service quality yang diterima pelanggan Lazada.co.id, dapat mempengaruhi kepuasan konsumennya.

Hasil penelitian ini didukung hasil penelitian terdahulu oleh Kassim \& Abdullah (2010) yang menyebutkan bahwa perceived service quality mempunyai pengaruh pada customer satisfaction. Dengan memastikan tingkat $e$-service quality yang tinggi, para manajer dapat memicu reaksi positif dari pelanggan yang merupakan kunci pertumbuhan yang sustainable untuk e-shop (Gounaris, Dimitriadis, \& Stathakopoulos, 2010).

Oleh karena itu, dapat ditarik kesimpulan bahwa semakin kuat e-service quality yang dirasakan oleh pelanggan Lazada.co.id, maka semakin tinggi tingkat satisfaction yang dirasakan pelanggan.

Hasil pengolahan data menunjukkan bahwa sebagian besar responden memberikan penilaian yang baik terhadap e-service quality Lazada.co.id dan penilaian responden juga menunjukkan tingkat kepuasan yang cukup tinggi. Artinya, secara keseluruhan Lazada telah memberikan e-service quality yang baik pada pelanggannya, yaitu dari sisi kemudahan dan kecepatan untuk mengakses dan menggunakan website, reliabilitas sistem, pemenuhan pesanan, dan keamanan website.

Uji hipotesis penelitian ini menunjukkan bahwa satisfaction memiliki hubungan positif terhadap behavioral intentions. Standard coefficients yang bernilai 1.690 menunjukkan adanya korelasi antara satisfaction dengan behavioral intentions, namun bukan merupakan korelasi yang 
kuat. Hal ini menunjukkan bahwa tingginya satisfaction yang dirasakan pelanggan Lazada.co.id dapat mempengaruhi behavioral intentions mereka.

Hasil penelitian ini didukung hasil penelitian terdahulu oleh penelitian Gounaris, Dimitriadis, \& Stathakopoulos (2010) yang menyebutkan bahwa tingginya quality dan satisfaction mendorong site revisit serta word-ofmouth dan penelitian oleh Lee \& Lin (2005) yang menyatakan bahwa customer satisfaction berpengaruh secara signifikan pada customer purchase intentions. Pelanggan yang puas, enggan untuk berpindah pada retailer lain hanya untuk benefit jangka pendek (Mukherjee \& Nath, 2007).

Oleh karena itu, dapat ditarik kesimpulan bahwa semakin tinggi satisfaction yang dirasakan oleh pelanggan Lazada.co.id, maka semakin tinggi behavioral intentions mereka.

Hasil pengolahan data menunjukkan bahwa sebagian besar responden memiliki tingkat kepuasan yang baik terhadap Lazada.co.id dan penilaian responden juga menunjukkan behavioral intentions yang cukup baik, terutama pada word-of-mouth. Artinya, secara keseluruhan Lazada telah membuat pelanggannya puas, sehingga pelanggan Lazada.co.id bersedia untuk menyebarkan hal positif tentang Lazada.co.id, melakukan pembelian kembali dan mengunjungi kembali Lazada.co.id.

\section{Simpulan dan Saran}

Berdasarkan analisis hasil penelitian menggunakan metode Structural Equation Modeling (SEM) untuk menganalisa pengaruh antara e-service quality, satisfaction dan trust terhadap behavioral intentions. Maka, dapat diambil kesimpulan sebagai berikut :

1. $\begin{aligned} & \text { E-Service quality } \\ & \text { pengaruh } \\ & \text { satisfaction. }\end{aligned}$

2. E-Service quality tidak mempunyai pengaruh secara langsung terhadap behavioral intentions.

3. Satisfaction memiliki pengaruh positif dengan behavioral intentions

4. Trust mempunyai pengaruh positif terhadap behavioral intentions,

Saran

Berdasarkan hasil penelitian, maka peneliti mengajukan saran bagi Lazada.co.id sebagai berikut :

1. Lazada.co.id dapat meningkatkan kualitas pelayanan dari customer service-nya. Disarankan agar staf customer service memiliki ketrampilan yang lebih baik dalam menangani masalah teknis yang terjadi, serta lebih responsif dalam menangani masalah yang tengah dialami oleh pelanggan. Karena masih ada sejumlah pelanggan yang masih mengeluhkan tentang pelayanan dari customer service Lazada.co.id. Hal ini dapat meningkatkan profesionalitas Lazada.co.id di mata pelanggan, sehingga pelanggan dapat lebih percaya pada Lazada.co.id sebagai perusahaan profesional yang memahami kepentingan pelanggannya.

2. Akan lebih baik jika Lazada.co.id memberikan perhatian khusus pada fulfillment khususnya dalam hal pengiriman barang. Karena, cukup banyak konsumen yang mengeluhkan tentang keterlambatan pengiriman barang. Lamanya keterlambatan dapat mencapai hitungan minggu, sehingga dapat dianggap masalah yang cukup serius. Lazada.co.id perlu berkomunikasi dengan partner logistik pengiriman barangnya untuk menetapkan standar pengiriman yang lebih baik. Standar pengiriman dapat dikatakan baik apabila lamanya pengiriman dapat bersaing dengan kompetitorkompetitornya, lamanya 
keterlambatan masih dalam batas wajar dan profesional dalam menghadapi keluhan pelanggan. Jika partner yang sekarang tidak mampu menyelesaikan masalah ini, maka solusi lain yang dapat diambil adalah mencari partner baru. Hal ini perlu dilakukan untuk tetap menjaga reputasi Lazada.co.id sebagai perusahaan yang nyaman untuk berbelanja online, sehingga pelanggan tetap percaya pada Lazada.co.id dan merasa bahwa Lazada.co.id memberikan pelayanan yang baik.

3. Lazada.co.id dapat mempertimbangkan untuk memperketat penyaringan merchant partner-nya. Karena beberapa pelanggan masih mengeluhkan bahwa ada merhant di Lazada yang tidak memberikan penjelasan yang jujur dan detil. Seperti yang ditemuinya bahwa ada produk KW atau palsu yang tidak diberi keterangan bahwa itu bukanlah produk original. Hal ini dapat merusak kepercayaan konsumen terhadap Lazada.co.id, sehingga pemilihan merchant perlu diperketat lagi agar sesuai dengan value Lazada.co.id. Untuk para merchant yang telah bergabung dengan Lazada.co.id, dapat disarankan untuk memberikan detil barang secara jujur dan siap untuk bertanggung jawab penuh jika nantinya ditemukan adanya penyimpangan., serta memberikan respon yang lebih cepat dalam pengiriman barang. Karena, beberapa pelanggan mengeluhkan produk-produk yang dibeli dari merchant sering terlambat dikirimkan.

4. Lazada.co.id dapat mempertimbangkan untuk meningkatkan kapasitas server agar dapat menangani traffic pengunjung yang besar. Cukup banyak responden yang mengeluhkan website Lazada.co.id yang sulit diakses pada saat diadakan flash sale. Hal ini sangat mengganggu mereka yang berpartisipasi maupun yang tidak berniat berpartisipasi dalam flash sale.

5. Berdasarkan masukan kualitatif dari responden, masih ada responden yang menemukan error ketika masuk ke laman pembayaran dan sistem filter produk yang terkadang tidak berfungsi dengan baik. Maka, akan lebih baik jika Lazada.co.id selalu mengecek kembali fungsi websitenya dan memperbaiki segala bugs dan error yang ada. Lazada.co.id dapat meminta masukan dari pelanggan yang memakainya untuk mendeteksi bugs dan error.

6. Masalah lain yang dialami pelanggan terkait fulfillment adalah lamanya verifikasi pembayaran melalui transfer bank, kesalahan input resi pengiriman, paket diterima dalam kondisi packing yang penyok hingga kesalahan pengiriman barang. Akan lebih baik jika Lazada.co.id melatih staf yang menangani masalah pesanan barang untuk dapat lebih teliti dan cepat dalam memproses pesanan.

7. Berdasarkan penilaian kualitatif responden, beberapa dari mereka ada yang menyebutkan bahwa penataan home page Lazada.co.id terlalu ramai dan perlu penataan yang lebih baik. Hal ini juga menyebabkan loading website menjadi berat. Lazada.co.id dapat mempertimbangkan agar penataan halaman utama atau homepage Lazada.co.id dapat dibuat lebih sederhana dan rapi, sehingga dapat membuat pelanggan lebih nyaman memandangnya. Hal ini 
berpengaruh pada aspek aesthetics yang merupakan bagian dari eservice quality.

8. Beberapa responden menyarankan agar produk-produk di Lazada.co.id lebih lengkap dan variatif lagi. Selain itu, cukup banyak responden yang menginginkan agar jangkauan wilayah COD diperluas dan semua produk dapat menggunakan pilihan COD. Maka, Lazada.co.id dapat mempertimbangkan untuk memperlengkap lagi setiap kategori produk agar pelanggan dapat mencari seluruh produk yang dibutuhkan hanya dalam satu tempat. Selain itu, dapat dipertimbangkan juga untuk memperluas jangkauan COD, sehingga pelanggan lebih puas dalam berbelanja di Lazada.co.id.

9. Sejumlah pelanggan menginginkan adanya promosi diskon yang lebih banyak dan lebih sering. Harga yang menarik memang adalah keinginan pelanggan pada umumnya. Tetapi, memberikan potongan harga tentunya bukanlah saran yang menarik bagi perusahaan karena akan berdampak pada berkurangnya keuntungan perusahaan. Namun, Lazada.co.id dapat mempertimbangkan sebuah solusi yang dapat menjadi win-win solution atas hal ini. Salah satu cara yang dapat dipertimbangkan adalah membuat loyalty program. Jadi, potongan harga diberikan berdasarkan tingkat loyalitas pelanggan. Misalnya, semakin sering pelanggan membeli produk dari Lazada.co.id (dapat ditelusuri dari history pembeliannya), maka semakin besar tambahan diskon yang akan diterima oleh pelanggan. Hal ini dapat membuat para pelanggan lebih puas, sekaligus mendorong mereka untuk berbelanja lebih banyak di Lazada.co.id.
10. Akan lebih baik apabila Lazada.co.id membuat program kampanye untuk meningkatkan kepercayaan pelanggan pada keamanan Lazada.co.id untuk berbelanja online. Karena berdasarkan penilaian pelanggan, mereka masih kurang percaya terhadap Lazada.co.id mengenai keamanan informasi pribadinya.

11. Sejumlah pelanggan masih menemukan ketidakcocokan antara informasi stok produk yang tertera di website dengan informasi stok aktualnya. Solusi yang mungkin dapat dilakukan adalah menerapkan sistem ERP logistik yang terintegrasi dengan website Lazada.co.id, misalnya dengan sistem RFID dan dihubungkan dengan website, sehingga informasi stok produk memungkinkan untuk di-update secara real time dan stok produk tidak perlu di-update secara manual untuk menghindari kesalahan memasukkan data.

Selain itu peneliti juga mengajukan saran bagi penelitian selanjutnya sebagai berikut

1. Penelitian ini terbatas pada penilaian terhadap website Lazada.co.id saja. Namun, melihat tren kedepan bahwa semakin banyak pengakses internet dari mobile atau smartphone dibandingkan dengan desktop, maka perlu dipertimbangkan untuk melakukan penelitian dari sisi aplikasi mobile Lazada.co.id. Survey Markplus Insight tahun 2013 menunjukkan bahwa $86 \%$ responden mengakses internet melalui Smartphone, $\quad 42,3 \% \quad$ yang mengaksesnya lewat laptop pribadinya, $15,2 \%$ mengaksesnya lewat laptop/pc kantor dan hanya $10,6 \%$ yang mengakses lewat laptop/pc di rumah (Markplus Insight, 2013). 
Mempertimbangkan kemiripan elemen dari website dengan aplikasi mobile dan setiap variabel dan dimensi dari model penelitian ini relevan dengan elemen tersebut. Maka, penelitian selanjutnya pada sisi aplikasi mobile dapat menggunakan model penelitian yang sama.

2. Penelitian ini dibatasi pada empat variabel, yaitu e-service quality dengan dimensinya efficiency, system availability, fulfillment, privacy, dan aesthetics; satisfaction; trust; dan behavioral intentions dengan dimensinya word-of-mouth, repurchase intentions, dan site revisit.

Pada penelitian selanjutnya, variabel penelitian dapat ditambahkan lagi dengan variabel-variabel baru yang terkait dengan satisfaction atau behavioral intentions, salah satunya adalah variabel Product Portfolio yang mempengaruhi satisfaction (Zeng, Hu, Chen, \& Yang, 2009).

Peneliti juga menyarankan untuk mengukur masing-masing dimensi eservice quality, yaitu efficiency, system avaliability, fulfillment, privacy, aesthetics dengan hubungannya pada word-of-mouth, repurchase intentions dan site revisit. Hal ini dimaksudkan agar dapat diperoleh hasil penelitian yang lebih detil dan dapat diketahui besarnya pengaruh masing-masing variabel tersebut pada word-of-mouth, repurchase intentions, site revisit dan satisfaction. Sehingga, disarankan agar tidak menggunakan variabel berdimensi, melainkan menjadikan masing-masing dimensi e-service quality dan intentions sebagai variabel yang berdiri sendiri.

3. Penelitian ini terbatas pada responden yang tergolong Net
Generation, yakni mereka yang berumur anatara 17-35 tahun. Penelitian selanjutnya dapat meneliti golongan Generasi X yang berumur lebih tua namun memiliki kondisi finansial yang lebih mapan, sehingga sangat potensial untuk menjadi pelanggan perusahaan online.

4. Penelitian selanjutnya dapat menggunakan indikator-indikator baru untuk variabel fulfillment, karena pada penelitian ini ditemukan bahwa variabel fulfillment kurang reliabel. Sehingga, diperlukan indikator-indikator yang lebih reliabel untuk mengukur fulfillment. Salah satu jurnal acuan yang dapat dipakai adalah jurnal dari Zeng, $\mathrm{Hu}$, Chen, \& Yang (2009).

5. Peneliti menyarankan untuk meninjau kembali dan menambahkan indikator-indikator untuk variabel efficiency. Karena pada akhirnya, variabel efficiency hanya memiliki 3 indikator yang valid dan nilai AVEnya 0.505 yang mendekati kategori kurang reliabel.

6. Penelitian selanjutnya dapat menerapkan model pada objek penelitian lain dalam industri ecommcerce seperti OLX, Bhinneka.com, Zalora, Qoo10, Tokopedia dan lainnya. Objek-objek penelitian tersebut penting karena berdasarkan survey Nusa Research (2014), perusahaan-perusahaan tersebut memiliki market share yang cukup besar di pasar e-commerce Indonesia.

\section{REFERENSI}

Afsar, A., Nasiri, Z., \& Zadeh, M. O. (2013). E-loyalty Model in eCommerce. Mediterranean Journal of Social Sciences , 4 (9). 
American Society for Quality. (2014).

Quality Glossary. Dipetik Maret 29, 2014, dari ASQ:

http://asq.org/glossary/q.html

APJII. (2012). Profil Pengguna Internet Indonesia 2012.

Boston Consulting Group. (2001). Winning the Online Consumer 2.0. The Boston Consulting Group.

Brilliant, M. A., \& Achyar, A. (2013). The Impact of Satisfaction and Trust on Loyalty of E-Commerce Customers. ASEAN Marketing Journal , 5 (1).

Chaffey, D. (2007). E-Business and ECommerce Management. Harlow: Pearson.

Cyr, D. (2008). Modeling Website Design across Cultures: Relationship to Trust, Satisfaction and E-loyalty. Journal of Management Information Systems, 24 (4).

Dictionary: American Marketing Association. (2014). Dipetik Maret 23, 2014, dari American Marketing Association: https://www.ama.org/resources/Pag es/Dictionary.aspx?dLetter=E

Egger, F. N. (2001). Affective Design of E-Commerce User Interfaces : How to Maximise Perceived

Trustworthiness. Asean Academic Press .

Egger, F. N. (2000). “Trust Me, I'm an Online Vendor": Towards a Model of Trust for E-Commerce System Design. Extended Abstracts on Human Factors in Computing Systems .

Fishbein, M., \& Ajzen, I. (1975). Belief, Attitude, Intention, and Behavior: An Introduction to Theory and Research. Addison-Wesley.
George, D., \& Mallery, P. (2003). SPSS for Windows step by step: A simple guide and reference. Boston: Allyn \& Bacon.

Ghozali, H. I. (2006). Aplikasi Analisis Multivariate dengan Program SPSS (Vol. 4). Badan Penerbit Universitas Diponegoro.

Gliem, J. A., \& Gliem, R. R. (2003). Calculating, Interpreting, and Reporting Cronbach's Alpha Reliability Coefficient for LikertType Scales. Midwest Research-toPractice Conference in Adult, Continuing, and Community Education, (hal. 87). Ohio.

Gounaris, S., Dimitriadis, S., \& Stathakopoulos, V. (2010). An examination of the effects of service quality and satisfaction on customers' behavioral intentions in e-shopping. Journal of Services Marketing , 24 (2).

Hair, J. F., Black, W. C., \& Anderson, R. E. (2010). Multivariate Data Analysis. Pearson.

Harris, L. C., \& Goode, M. M. (2010). Online servicescapes, trust, and purchase intentions. Journal of Services Marketing .

Hellier, P. K., Geursen, G. M., Carr, R. A., \& Rickard, J. A. (2003). Customer Repurchase Intention. European Journal of Marketing , 37 (11/12), 1762-1800.

Kartajaya, H., Hermawan, M., Mussry, J., Taufik, Yuswohady, \& Setiawan, I. (2010). Marketing in Indonesia.

Kassim, N., \& Abdullah, N. A. (2010). The effect of perceived service quality dimensions on customer satisfaction, trust, and loyalty in ecommerce settings. 22 (3). 
Keaveney, S. M., \& Parthasarathy, M. (2001). Customer Switching Behavior in Online Services: An Exploratory Study of the Role of Selected Attitudinal, Behavioral, and Demographic Factors. Journal of the Academy of Marketing Science, 42-58.

(2014). Kinnevik Q1 2014 Presentation.

(2014). Kinnevik Rocket Capital Markets Day Presentation.

Kominfo.go.id. (2014, November 24). Pengguna Internet Indonesia Nomor Enam Dunia. Diambil kembali dari Kementrian Komunikasi dan Informatika Republik Indonesia: http://kominfo.go.id/index.php/cont ent/detail/4286/Pengguna+Internet+ Indonesia+Nomor+Enam+Dunia/0/s orotan_media\#.VMSAHP6Uf6N

Kompas.com. (2014, April 9). 4 Tantangan Bisnis "E-commerce" di Indonesia. Diambil kembali dari Tekno Kompas: http://tekno.kompas.com/read/2014/ 04/06/1203132/4.tantangan.bisnis.ecommerce.di.indonesia

Kompas.com. (2013, April 15). Kasus Penipuan Dominasi Kejahatan "Cyber". Diambil kembali dari Kompas.com: http://tekno.kompas.com/read/2013/ 04/15/22095149/kasus.penipuan.do minasi.kejahatan.quotcyberquot

Kompas.com. (2013, Juni 21). Lazada Dapat Suntikan Dana 100 Juta Dollar. Dipetik Mei 19, 2014, dari Kompas.com: http://tekno.kompas.com/read/2013/ 06/21/11123312/Lazada.Dapat.Sunt ikan.Dana.100.Juta.Dollar
Kotler, P., \& Keller, K. L. (2012). Marketing Management (Vol. 14). Pearson.

Lazada Indonesia. (2014, September). Lazada Indonesia Fan Page. Diambil kembali dari Facebook: https://www.facebook.com/LazadaI ndonesia?ref=br_tf

Lazada.co.id. (2014). Diambil kembali dari Lazada.co.id.

Lee, G.-G., \& Lin, H.-F. (2005). Customer perceptions of e-service quality in online shopping. International Journal of Retail \& Distribution Management, 33.

Leiner, B. M., Cerf, V. G., Clark, D. D., Kahn, R. E., Kleinrock, L., Lynch, D. C., et al. (1999, Januari 23). A Brief History of the Internet. Dipetik Maret 23, 2014, dari Cornell University Library: http://arxiv.org/html/cs.NI/9901011

Limbu, Y. B., Wolf, M., \& Lunsford, D. (2012). Perceived ethics of online retailers and consumer behavioral intentions. Journal of Research in Interactive , 133-154.

Malhotra, N. K. (2009). Basic Marketing Research. New Jersey: Pearson.

Malhotra, N. K. (2010). Marketing Research : An Applied Orientation. New Jersey: Pearson.

Marketeers. (2013, November 1). Konsumen Lebih Peduli Keamanan Bertransaksi Online Dibanding Harga. Diambil kembali dari Marketeers: http://www.themarketeers.com/archives/konsumen -lebih-peduli-keamananbertransaksi-online-dibandingharga.html\#.UypvhPmSyrk 
Marketeers. (2013, Oktober 30). MarkPlus Insight: Hanya 20\% Netizen yang Belanja Online. Dipetik Maret 23, 2014, dari Marketeers:

http://www.themarketeers.com/archives/markplusinsight-hanya-20-netizen-yangbelanja-online-.html\#.Uy50v_mSyrl

Marketeers. (2013, Oktober 30). MarkPlus Insight: Pengguna Internet Indonesia 74 Juta di Tahun 2013. Dipetik Maret 23, 2014, dari Marketeers: http://www.themarketeers.com/archives/Indonesia \%20Internet\%20Users.html\#.Uy5Vf fmSyrk

Markplus Insight. (2013). Indonesia Netizen Survey.

Mayer, R. C., Davis, J. H., \& Schoorman, F. D. (1995). An Integrative Model of Organizational Trust. The Academy of Management Review , 709-734.

Morgan, R. M., \& Hunt, S. D. (1994). The Commitment-Trust Theory of Relationship Marketin. The Journal of Marketing , 20-38.

Mukherjee, A., \& Nath, P. (2007). Role of electronic trust in online retailing. European Journal of Marketing , 41 (9/10).

Nielsen. (2013). Global Trust in Advertising and Brand Messages.

Nusa Research. (2014). E-Commerce Indonesia.

Parasuraman, A., Zeithaml, V. A., \& Berry, L. L. (1985). A Conceptual Model of Service Quality and Its Implications for Future Research. Journal of Marketing .

Parasuraman, A., Zeithaml, V. A., \& Malhotra, A. (2005). E-S-QUAL a Multiple-Item Scale for Assessing
Electronic Service Quality. Journal of Service Research .

Reichheld, F. F., \& Sasser, J. W. (1990). Zero Defections: Quality Comes to Services. Harvard Business Review

Reichheld, F. F., \& Schefter, P. (2000). ELoyalty: Your Secret Weapon on the Web. Harvard Business Review

Rosen, S. (2001, April 21). Sticky website is key to success. Communication World.

Sahin, A., Zehir, C., \& Kitapci, H. (2011). The Effects of Brand Experiences, Trust and Satisfaction on Building Brand Loyalty. Procedia Social and Behavioral Sciences, 1288-1301.

Schiffman, L. G., \& Kanuk, L. L. (2010). Consumer Behavior. New Jersey: Pearson.

Startupbisnis.com. (2014, Juni 12). Hal Hal Menarik dari Riset Perilaku ECommerce Indonesia oleh IDEA @EcommerceID. Diambil kembali dari Startupbisnis.com: http://startupbisnis.com/hal-halmenarik-dari-riset-perilaku-ecommerce-indonesia-oleh-ideaecommerceid/

Strauss, J., \& Frost, R. (2009). EMarketing. New Jersey: Pearson.

SWA. (2013). Maximilan Bittner: Target Lazada Jadi E-Commerce Terbesar di Indonesia. Diambil kembali dari SWA: http://swa.co.id/ceointerview/maximilan-bittner-targetlazada-jadi-e-commerce-terbesar-diindonesia

Tan, Y.-H., \& Thoen, W. (2001). Toward a Generic Model of Trust for Electronic Commerce. International 
Journal of Electronic Commerce, 61-74.

Tapscott, D. (2009). Grown Up Digital How the Net Generation Is Changing Your World.

Techinasia.com. (2014, Desember 1). Lazada reels in \$250M funding led by Temasek, bringing total to $\$ 650 M$. Diambil kembali dari Techinasia: https://www.techinasia.com/lazada250m-funding/

The Next Web. (2013, Agustus 13). Any small business in Southeast Asia can now set up a virtual shop on Amazon-like Lazada. Dipetik Mei 19, 2014, dari The Next Web: http://thenextweb.com/asia/2013/08/ 13/any-small-business-in-southeastasia-can-now-set-up-a-virtual-shopon-amazon-like-lazada/

TradingEconomics.com. (2014). Indonesia Retail Sales YoY. Retrieved from Trading Economics: http://www.tradingeconomics.com/i ndonesia/retail-sales-annual

VelaAsia.com. (2013, June 11). Indonesian eCommerce market size to double in 2013 to $\$ 8$ billion USD. Retrieved from Vela Asia: http://www.velaasia.com/indonesian -ecommerce-market-size-to-doublein-2013/

Venture Beat. (2013, Juni 20). Samwer brothers-backed Lazada nabs $\$ 100 M$ to be the 'Amazon of Southeast Asia'. Dipetik Maret 23, 2014, dari Venture Beat: http://venturebeat.com/2013/06/20/1 azada-funding/
Venture Beat. (2013, June 20). Samwer brothers-backed Lazada nabs $\$ 100 M$ to be the 'Amazon of Southeast Asia'. Dipetik March 23, 2014, dari Venture Beat: http://venturebeat.com/2013/06/20/1 azada-funding/

Wee, C. H., Lim, L. S., \& Lwin, M. (1995). General Perception of Word-of-Mouth Communication as a Source of Information: The Case of Singapore. Asia-Australia Marketing Journal , 3 (1).

Wijanto, S. H. (2008). Structural Equation Modeling dengan LISREL 8.8. Yogyakarta: Graha Ilmu.

Yang, Z., \& Fang, X. (2004). Online service quality dimensions and their relationships with satisfaction. International Journal of Service Industry Management, 15 (3).

Zeithaml, V. A., Berry, L. L., \& Parasuraman, A. (1996). The Behavioral Consequences of Service Quality. Journal of Marketing .

Zeithaml, V. A., Parasuraman, A., \& Malhotra, A. (2002). Service Quality Delivery Through Web Sites: A Critical Review of Extant Knowledge. Journal of the Academy of Marketing Science .

Zeng, F., Hu, Z., Chen, R., \& Yang, Z. (2009). Determinants of online service satisfaction and their impacts on behavioral intentions. Total Quality Management, 953969. 